\title{
The M. S. Roberts Site (41HE8): Archaeological Investigations at a Caddo Mound Site in the Upper Neches River Basin in East Texas
}

Timothy K. Perttula

Heritage Research Center, Stephen F. Austin State University

Mark Walters

Heritage Research Center, Stephen F. Austin State University

Bo Nelson

Heritage Research Center, Stephen F. Austin State University

Follow this and additional works at: https://scholarworks.sfasu.edu/ita

Part of the American Material Culture Commons, Archaeological Anthropology Commons, Environmental Studies Commons, Other American Studies Commons, Other Arts and Humanities Commons, Other History of Art, Architecture, and Archaeology Commons, and the United States History Commons

Tell us how this article helped you.

This Article is brought to you for free and open access by the Center for Regional Heritage Research at SFA ScholarWorks. It has been accepted for inclusion in Index of Texas Archaeology: Open Access Gray Literature from the Lone Star State by an authorized editor of SFA ScholarWorks. For more information, please contact cdsscholarworks@sfasu.edu. 
The M. S. Roberts Site (41HE8): Archaeological Investigations at a Caddo Mound Site in the Upper Neches River Basin in East Texas

\section{Creative Commons License}

(c) (i) (8)

This work is licensed under a Creative Commons Attribution-NonCommercial 4.0 International License 


\title{
The M. S. Roberts Site (41HE8): Archaeological Investigations at a Caddo Mound Site in the Upper Neches River Basin in East Texas
}

\author{
Timothy K. Perttula, Mark Walters, and Bo Nelson
}

\section{Introduction and Previous Archaeological Work}

The first archaeological investigations at the M. S. Roberts site in the Caddo Creek valley of the upper Neches River basin in East Texas (Figure 1) was by University of Texas (UT) archaeologists in 1931 (Perttula 2016). In that work, UT archaeologists excavated a trench of unknown size in the ancestral Caddo mound at the site, and gathered a surface collection from the plowed cotton field around the mound.

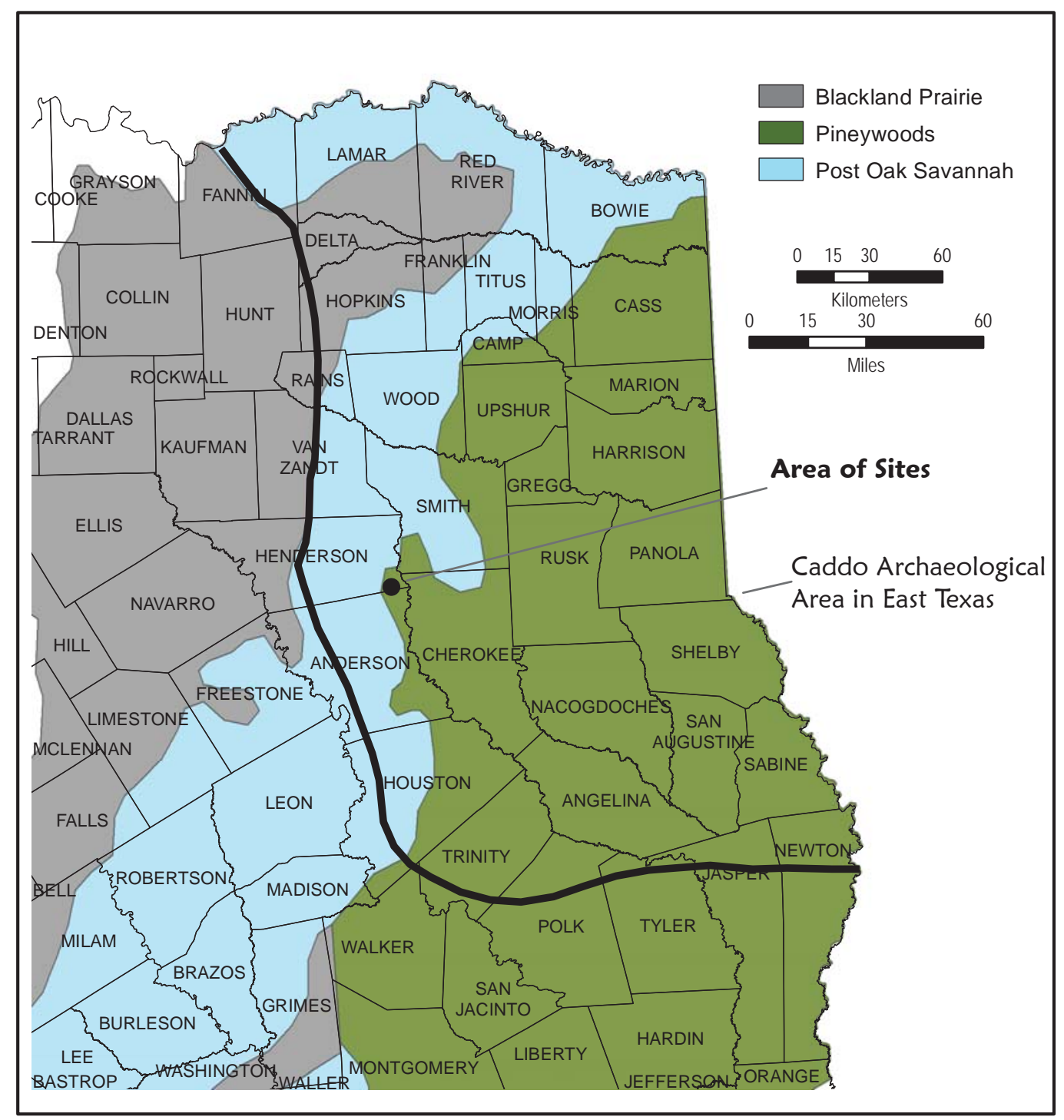

Figure 1. General location of the M. S. Roberts (41HE8) and Walter Brigham (41HE410) sites in East Texas. 
No further archaeological work was done at the site until January 2015 when a surface collection was obtained at the site with the permission of the landowners, Jim and Denise Renfroe (Perttula and Walters 2016). Later that year, a number of shovel tests and auger tests were excavated in and around the earthen mound, and an aerial survey of the site was done by Arlo McKee (University of Texas at Dallas) to map the topography of the landform, the earthen mound, and its associated borrow pit, as well as reconstruct changes in the shape and size of the mound between 1931 and 2015 (Perttula et al. 2016). The shovel and auger tests identified burned zones in the mound that were thought to represent the remains of burned Caddo buildings that stood on the mound, and also identified non-mound habitation deposits at the site.

In January 2016, again with the permission and support of the landowners, we returned to the M. S. Roberts site to conduct additional investigations, including remote sensing (see McKinnon et.al., this volume) of a 2.8 acre area over and around the mound, more shovel tests and the excavation of three $1 \times 1 \mathrm{~m}$ units (Units 1-3), and a surface reconnaissance of landforms to the east of the site to ascertain if the site boundaries continued to the east (see Appendix 1, this article). The main purpose of the latter archaeological work was three-fold: (1), to better define the spatial extent of non-mound archaeological deposits; (2), to locate and sample well-preserved non-mound habitation deposits and obtain charred plant remains for AMS dating; and (3) investigate the stratigraphic character of the mound deposits, identify cultural features in the mound, and hopefully obtain charred plant remains or unburned animal bones from these deposits for AMS dating.

\section{Excavations in the Mound}

Two 1 x 1 m units (Unit 1 and 3) were excavated in the mound at the M. S. Roberts site, one unit in each of the two mound lobes detected in the remote sensing (Figure 2). The southwestern corner of Unit 1 is at N88 E 45 in the remote sensing grid, while Unit 3's remote sensing grid coordinate is N70 E45 (Figure 3a-b).

Unit 1 excavations encountered a number of sediment zones in the mound below Zone 1, a dark yellowish-brown sandy loam plow zone (Figures 4a-b and 5a-b), and to a depth of ca. $105 \mathrm{~cm}$ bs at the bottom of the unit; the base of the mound was not exposed in either Unit 1 or 3 excavations. These include a brownish-gray sandy loam (Zone 2), with chunks of charcoal; a gray, grayish-brown, and brown sandy loam with gray clay inclusions (Zone 3); a yellowish-brown sandy loam (Zone 4); and a dark yellowish-brown sandy loam (Zone 5). A dark grayish-brown sandy loam with gray clay as well as charcoal flecks and chunks was visible at $101 \mathrm{~cm}$ bs in the floor of the unit. In the north wall profile (Figure 5b), Zone 2 has three subdivisions: $2 \mathrm{a}$, an orange and yellow mottled brown sandy loam; 2b, a dark yellowish-brown sandy loam with significant amounts of charred plant remains and wood charcoal chunks; and 2c, a yellowish-brown sandy loam with occasional charred remains; this zone is laminated or water-lain in the east wall profile. The top of Zone $2 \mathrm{c}$ is level with Zone 3 in the west wall profile. Zone 3 also has subdivisions: 3 a (visible in the south wall profile), orange and yellow mottles along with dark grayish-brown and dark yellowish-brown sandy loam mound fill; and $3 \mathrm{~b}$ (visible in the east wall), orange and yellow sandy loam with mottled clumps.

Our interpretation of the Unit 1 profile is that Zone 1 represents a plow zone, and Zones 2-6 are mound zones. Zone $2 \mathrm{~b}$ represents the remains of a burned Caddo building; a large piece of a burned mud dauber nest was recovered in situ in this zone at $31 \mathrm{~cm}$ bs. Zone 3-5 are mound fill zones over another burned and more deeply buried Caddo building in Zone 6 .

Unit 3 excavations did not encounter any clear evidence for burned Caddo buildings in the $100 \mathrm{~cm}$ high profile (Figure 6a-b). Rather, below the Zone 1 dark yellowish-brown sandy loam plow zone are Zones 2-4, each being mound fill deposits. Zone 2 is a yellowish-brown to dark yellowish-brown sandy loam with gray clay and orange/yellow mottles; Zone 3 is a yellowish-brown sandy loam with orange mottles; and Zone 4 is a mix of grayish-brown clay and yellowish-brown sandy loam. 


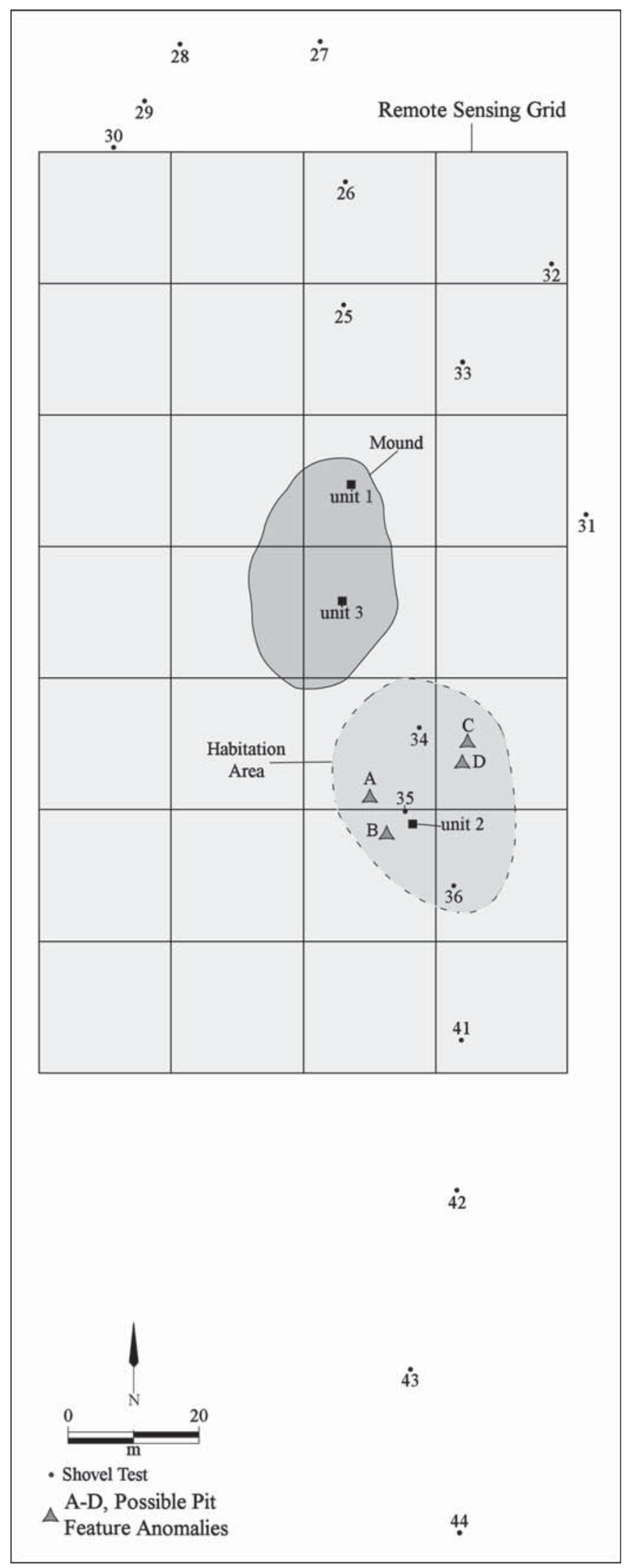

Figure 2. Location of the earthen mound at the M. S. Roberts site, significant habitation areas, Units 1-3, and additional shovel tests. 
a.

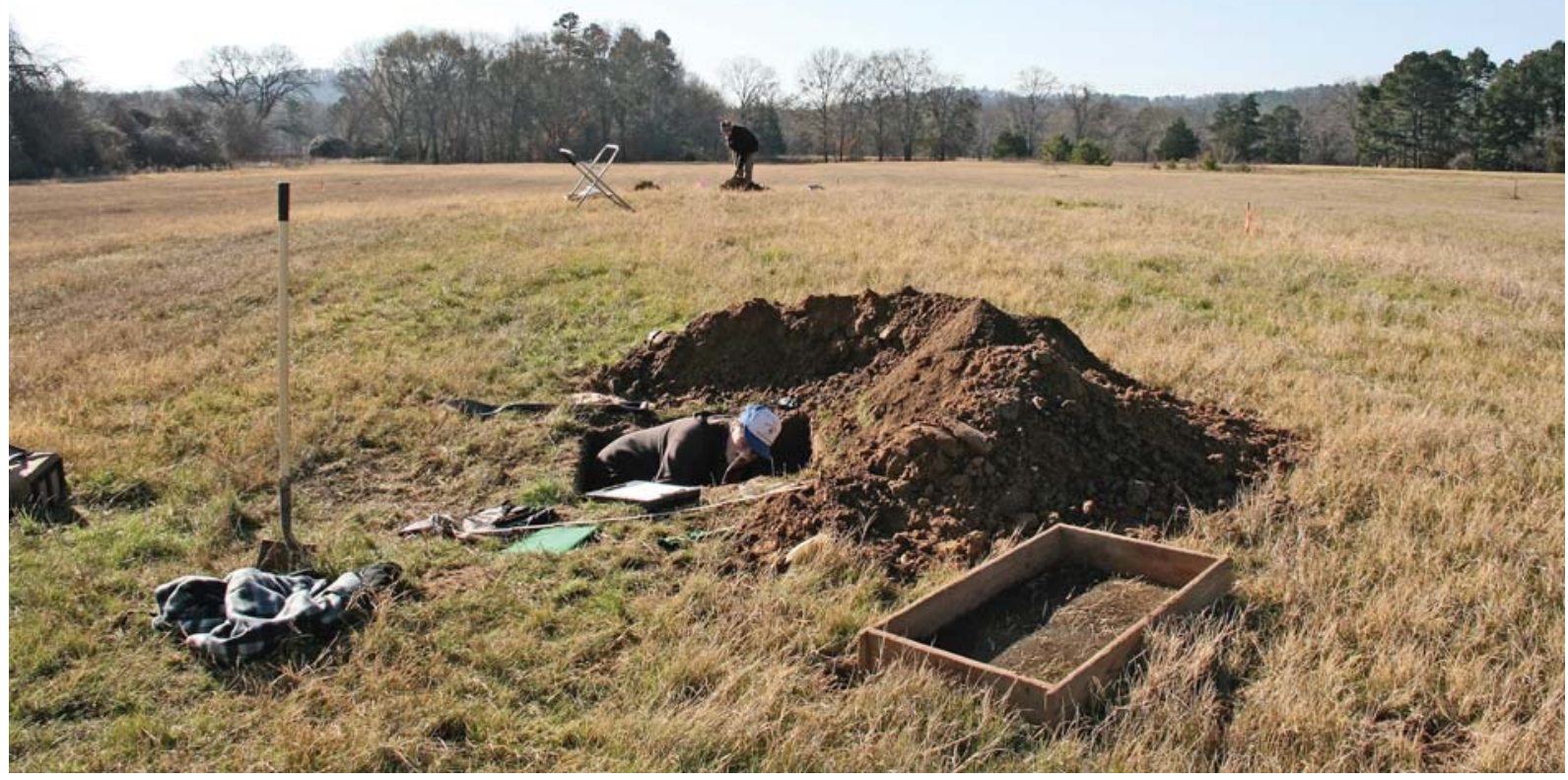

b.

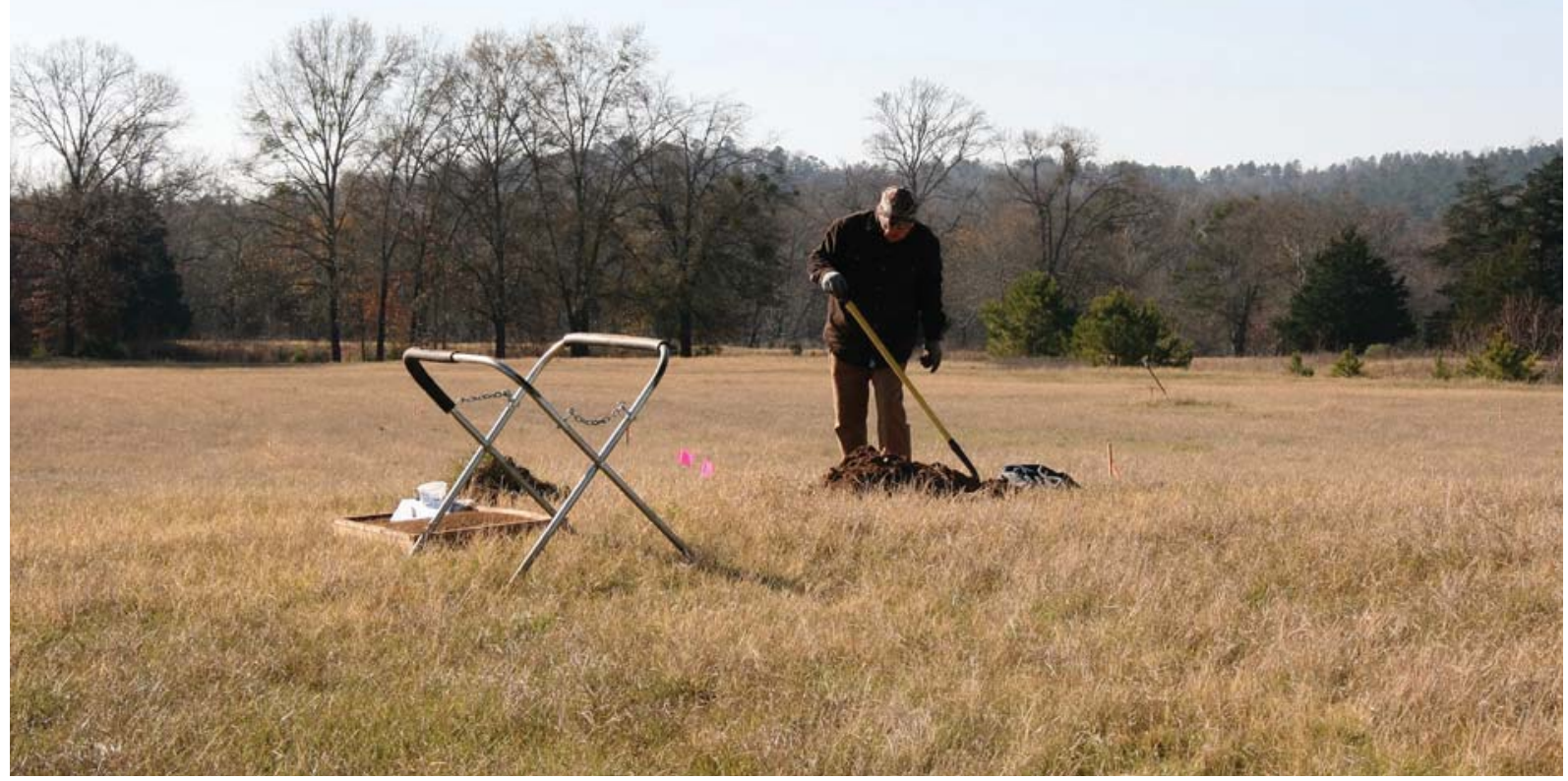

Figure 3. Unit excavations: a, looking south at Units 1 (foreground) and 3 (background) on the earthen mound at the M. S. Roberts site; b, looking south at Kevin Stingley beginning excavations in Unit 3. Photographs provided by Mark Walters. 

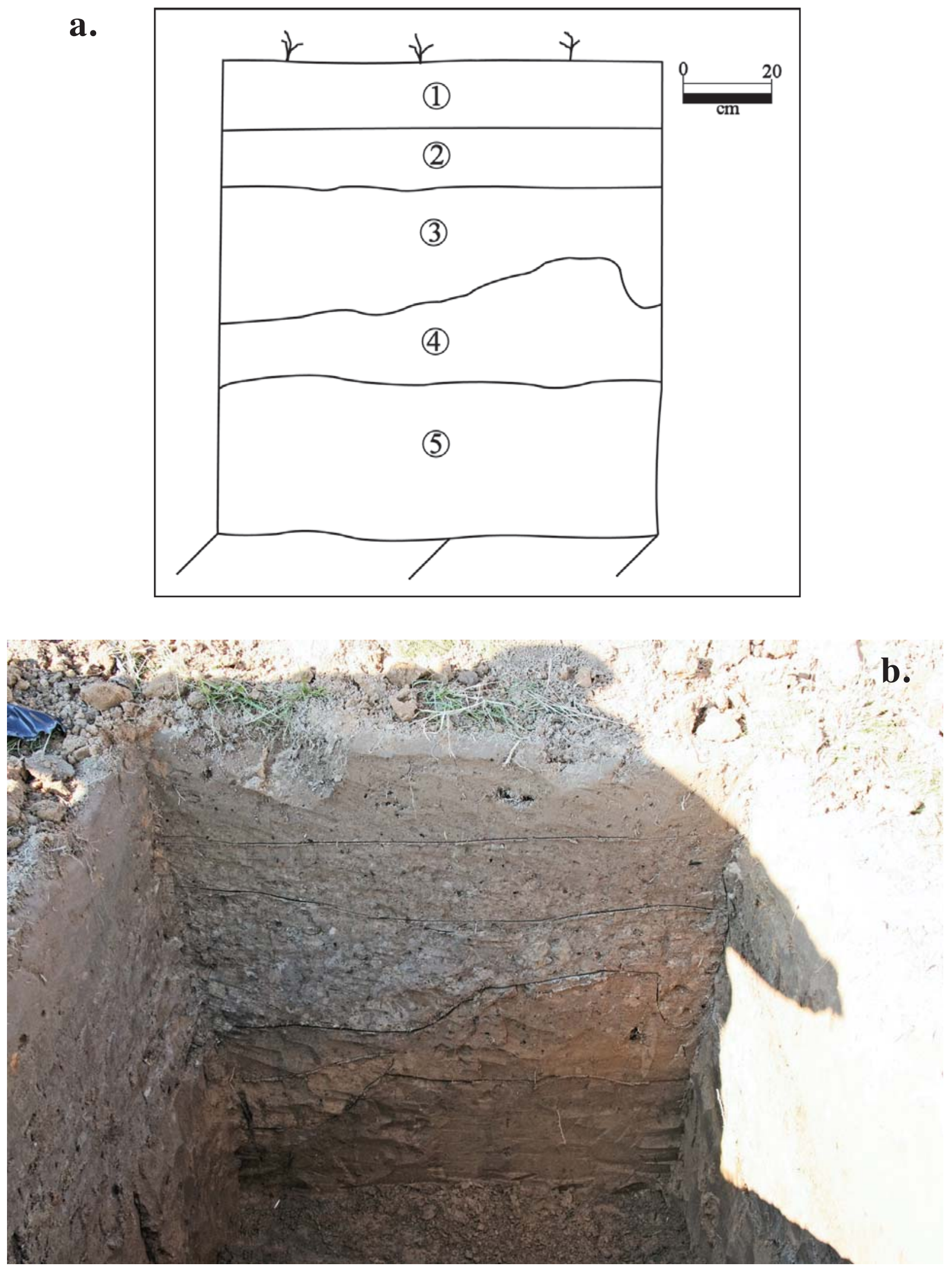

Figure 4. Unit 1, west wall profile: a, profile drawing; b, looking west (photograph provided by Mark Walters). 
28 Journal of Northeast Texas Archaeology 71 (2017)
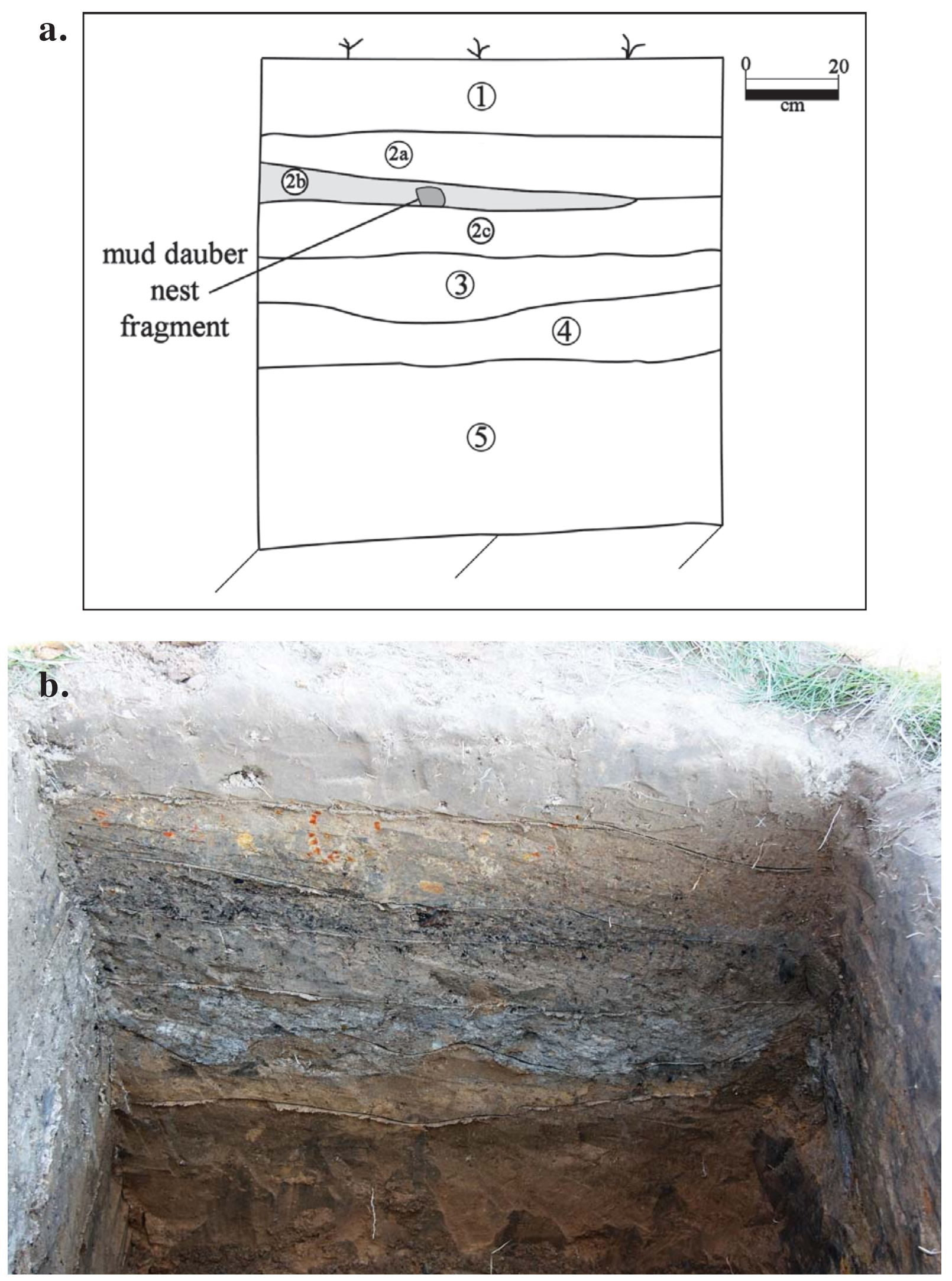

Figure 5. Unit 1, north wall profile: a, profile drawing; b, looking north (photograph provided by Mark Walters). 

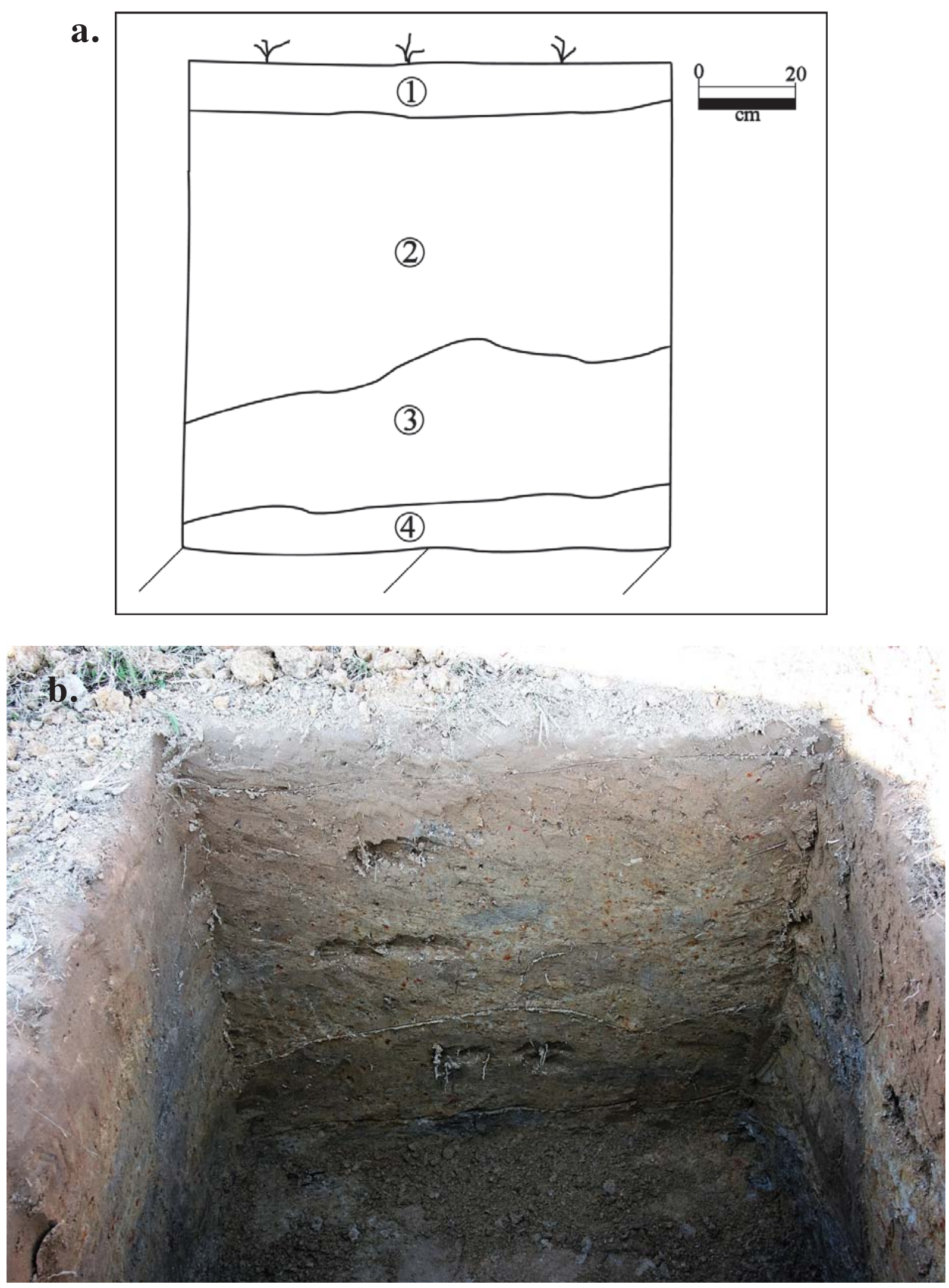

Figure 6. Unit 3, north wall profile: a, profile drawing; b, looking north (photograph provided by Mark Walters). 
Because of the difficulty in screening the archaeological deposits in the mound, due to the clay content of the mound fill zones, only the upper $35 \mathrm{~cm}$ of the deposits in Unit 1 were screened through $1 / 4$-inch mesh and only the upper $10 \mathrm{~cm}$ were screened in Unit 3 . These excavations recovered numerous ceramic vessel sherds in these deposits (approximately 71 percent of the total number of artifacts in the two units), animal bones and wood charcoal from various depths in Zones 2-4, and a large section of a mud dauber nest in Zone $2 \mathrm{~b}$ (Table 1).

Table 1. Distribution of artifacts from Units 1 and 3 on the mound at the M. S. Roberts site.

\begin{tabular}{lllllllll}
\hline $\begin{array}{l}\text { Depth } \\
(\mathrm{cm} \mathrm{bs})\end{array}$ & PS & DS & AB & WC & LD & MD & Other & N \\
\hline $0-10$ & 25 & 6 & - & - & 1 & - & 1 Mano & 33 \\
$10-20$ & 18 & 6 & 1 & - & 2 & - & 1 Mano & 28 \\
$20-30$ & 28 & 10 & 1 & 4 & - & - & 1 FCR & 44 \\
$30-35$ & 9 & 4 & - & 5 & - & 1 & - & 19 \\
37 & - & - & 4 & - & - & - & - & 7 \\
54 & - & - & 7 & - & - & - & - & 3 \\
77 & - & - & 3 & - & - & - & - & 11 \\
80 & - & - & - & 11 & - & - & - & 2 \\
Back dirt & 2 & - & - & - & - & - & - & 151 \\
\hline Totals & 82 & 26 & 16 & 20 & 3 & 1 & 3 & \\
\hline
\end{tabular}

$\mathrm{PS}=$ plain sherd; $\mathrm{DS}=$ decorated sherd; $\mathrm{AB}=$ animal bone; $\mathrm{WC}=$ wood charcoal; $\mathrm{LD}=$ lithic debris; $\mathrm{MD}=$ mud dauber nest fragment; FCR=fire-cracked rocks

\section{Excavations and Shovel Tests in off-Mound Areas}

Additional shovel tests both north, south, and east of the mound at the M. S. Roberts site has identified habitation deposits from an ancestral Caddo occupation over a ca. 18,000 square meter area (ca. 4.5 acres) of the landform. The best preserved habitation deposits that we have identified to date are in a ca. $35 \times 35 \mathrm{~m}$ area south and southeast of the southern end of the mound. Unit 2 (N36 E56 on the remote sensing grid) was excavated in this area (see Figure 2), adjacent to ST 35. Remote sensing work in this part of the site also suggested that there were likely cultural pit features in this area (see McKinnon et. al., this volume).

Unit 2 was excavated to $50 \mathrm{~cm}$ bs (Figure 7). Sediments in the unit included a ca. $15 \mathrm{~cm}$ thick yellowish-brown sandy loam plow zone (Zone 1), a ca. 6-7 cm thick mottled dark yellowish-brown sandy loam (Zone 2), and a dark yellowish-brown sandy loam zone (Zone 3) that extended to at least $50 \mathrm{~cm}$ bs. Zone 2 likely represents an unplowed portion of a shallowly buried Caddo occupation horizon. There were animal bone and charcoal flecks noted in the upper portion of Zone 3.

One possible cultural feature, likely a post hole, was identified in Zone 3, but apparently originated in Zone 2 (ca. 20-47 cm bs). This dark brown sandy loam stain was noted in the west wall profile, and is ca. $28 \mathrm{~cm}$ in diameter, with straight walls and a rounded base (see Figure 7). Ceramic vessel sherds were most abundant between $10-20 \mathrm{~cm}$ bs, ceramic pipe sherds occurred only between $20-30 \mathrm{~cm}$ bs, and wood charcoal and nutshell were recovered in habitation deposits between 20-50 $\mathrm{cm}$ bs (Table 2); 71 percent of the recovered artifacts are ceramic vessel sherds. 


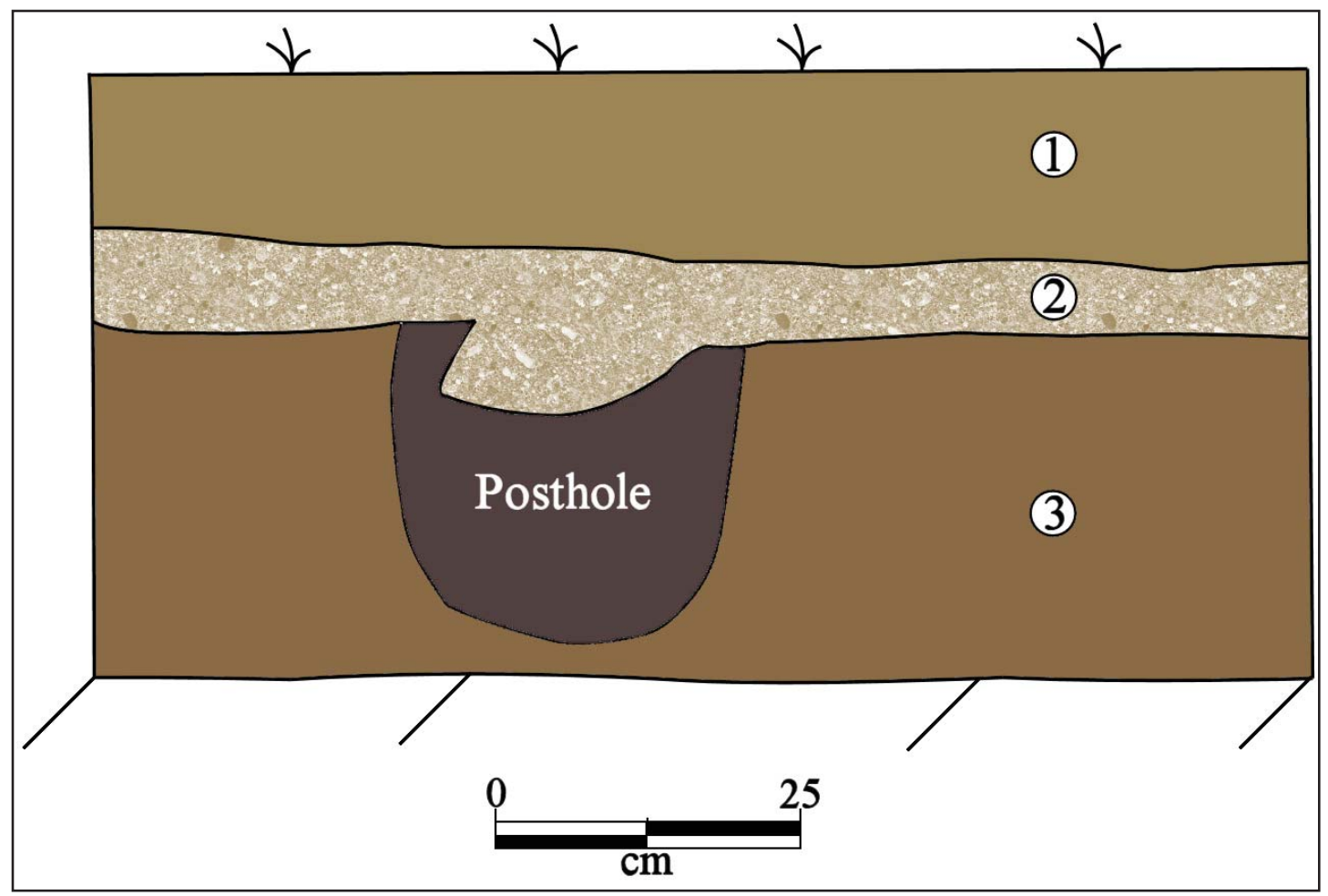

Figure 7. West wall profile of Unit 2 at the M. S. Roberts site.

Table 2. Distribution of artifacts from Unit 2 at the M. S. Roberts site.

\begin{tabular}{lccccccccc}
\hline $\begin{array}{l}\text { Depth } \\
(\mathrm{cm} \mathrm{bs})\end{array}$ & PS & DS & CPS & AB & WC & NS & LD & Other & N \\
\hline $0-10$ & 13 & 6 & - & - & - & - & 2 & - & 21 \\
$10-20$ & 23 & 11 & - & - & - & - & 6 & - & 40 \\
$20-30$ & 12 & 2 & 3 & - & 4 & 3 & 3 & - & 27 \\
$30-40$ & 17 & 4 & - & - & 1 & 3 & 3 & - & 28 \\
$40-50$ & 15 & 2 & - & - & 10 & 2 & 2 & 1 Mano & 32 \\
\hline Totals & 80 & 25 & 3 & - & 15 & 8 & 16 & 1 & 148 \\
\hline
\end{tabular}

$\mathrm{PS}=$ plain sherd; $\mathrm{DS}=$ decorated sherd; $\mathrm{CPS}=$ ceramic pipe sherd; $\mathrm{AB}=$ animal bone; $\mathrm{WC}=$ wood charcoal; NS=nutshell; $\mathrm{LD}=$ lithic debris

Fourteen of the shovel tests excavated at the M. S. Roberts site in January 2016 contained ancestral Caddo archaeological deposits and material culture remains (Table 3; see also Figure 2). The deposits are in relatively thick $(75+\mathrm{cm})$ yellowish-brown A- and E-horizon sediments. In ST 34, a dark brown sandy loam zone was recognized between $26-54 \mathrm{~cm}$, and this zone may be the unplowed portions of a buried ancestral Caddo occupation horizon; a fragment of a mud dauber nest was recovered between 40-60 cm bs in ST 34. A clay B-horizon was encountered in only one of these shovel tests (ST 30) in the northwestern part of the landform (see Figure 2), at $75 \mathrm{~cm}$ bs. 
Table 3. Descriptions of positive shovel tests at the M. S. Roberts site.

\begin{tabular}{|c|c|c|}
\hline ST Number & Description & Artifacts \\
\hline 25 & $0-100 \mathrm{~cm}+$, yellowish-brown sandy loam & ceramic sherds, $20-40 \mathrm{~cm}$ bs \\
\hline 26 & 0-100 cm+, yellowish-brown sandy loam & lithic debris, $0-20 \mathrm{~cm}$ bs \\
\hline 27 & $0-100 \mathrm{~cm}+$, yellowish-brown sandy loam & $\begin{array}{l}\text { ceramic sherds, } 20-40 \mathrm{~cm} \text { bs; } \\
\text { lithic debris, } 40-60 \mathrm{~cm} \mathrm{bs}\end{array}$ \\
\hline 28 & $0-100 \mathrm{~cm}+$, yellowish-brown sandy loam & ceramic sherds, $0-40 \mathrm{~cm}$ bs \\
\hline 30 & $\begin{array}{l}0-75 \mathrm{~cm} \text {, yellowish-brown sandy loam; } \\
75-79 \mathrm{~cm}+\text {, strong brown clay }\end{array}$ & $\begin{array}{l}\text { ceramic sherds, } 0-20 \\
\mathrm{~cm} \text { bs }\end{array}$ \\
\hline 31 & $\begin{array}{l}0-44 \mathrm{~cm} \text {, yellowish-brown sandy loam; } \\
44-50 \mathrm{~cm}+\text {, grayish-brown sandy loam }\end{array}$ & $\begin{array}{l}\text { ceramic sherds, } 0-20 \\
\mathrm{~cm} \text { bs }\end{array}$ \\
\hline 33 & $0-50 \mathrm{~cm}+$, yellowish-brown sandy loam & ceramic sherds, $0-40 \mathrm{~cm}$ bs \\
\hline 34 & $\begin{array}{l}\text { 0-26 cm, yellowish-brown sandy loam; } \\
26-54 \mathrm{~cm} \text {, dark brown sandy loam; } \\
54-60 \mathrm{~cm}+\text {, yellowish-brown sandy loam }\end{array}$ & $\begin{array}{l}\text { ceramic sherds, } 0-60 \mathrm{~cm} \text { bs; } \\
\text { animal bone, } 20-60 \mathrm{~cm} \text {; } \\
\text { mud dauber nest, } 40-60 \mathrm{~cm} \text { bs; } \\
\text { lithic debris, } 0-40 \mathrm{~cm} \mathrm{bs} \text {; } \\
\text { ceramic sherds, } 0-60 \mathrm{~cm} \mathrm{bs}\end{array}$ \\
\hline 35 & $0-78 \mathrm{~cm}+$, yellowish-brown sandy loam & $\begin{array}{l}\text { ceramic sherds, } 20-78 \mathrm{~cm} \mathrm{bs} \\
\text { lithic debris, } 20-40 \mathrm{~cm} \text { bs; } \\
\text { nutshell, } 40-60 \mathrm{~cm} \mathrm{bs} \\
\text { animal bone, } 40-60 \mathrm{~cm} \text { bs }\end{array}$ \\
\hline 36 & 0-60 cm+, yellowish-brown sandy loam & $\begin{array}{l}\text { ceramic sherds, } 0-40 \mathrm{~cm} \text { bs; } \\
\text { lithic debris, } 0-20 \mathrm{~cm} \mathrm{bs}\end{array}$ \\
\hline 41 & 0-101 cm+, yellowish-brown sandy loam & ceramic sherds, $40-60 \mathrm{~cm}$ bs \\
\hline 42 & $0-100 \mathrm{~cm}+$, yellowish-brown sandy loam & $\begin{array}{l}\text { ceramic sherds and } \\
\text { lithic debris } 0-20 \mathrm{~cm} \text { bs }\end{array}$ \\
\hline 43 & 0-100 cm+, yellowish-brown sandy loam & ceramic sherds, $40-60 \mathrm{~cm}$ bs \\
\hline 44 & 0-100 cm+, yellowish-brown sandy loam & lithic debris, $20-40 \mathrm{~cm}$ bs \\
\hline
\end{tabular}

Only low densities of artifacts have been recovered in shovel tests north and east of the earthen mound (Table 4; see also Figure 2), as well as in shovel tests ca. 60-120 m south of the mound. However, ST 34, ST 35, and ST 36 had artifact densities that range from 12-25 per shovel test, or ca. 96-200 artifacts per square meter of archaeological deposits. 
Table 4. Distribution of artifacts in surface collections and in the positive shovel tests at the M.S. Roberts site.

\begin{tabular}{lllllllll}
\hline ST No. & PS & DS & LD & AB & NS & BC & MD & N \\
\hline 25 & - & 1 & - & - & - & - & - & 1 \\
26 & - & - & 1 & - & - & - & - & 1 \\
27 & 1 & - & 1 & - & - & - & - & 2 \\
28 & 5 & - & - & - & - & - & - & 5 \\
30 & 1 & - & - & - & - & - & - & 1 \\
31 & 2 & - & - & - & - & - & - & 2 \\
33 & 3 & - & - & - & - & - & - & 12 \\
34 & 4 & 3 & 1 & 3 & - & - & 1 & 25 \\
35 & 14 & 4 & 4 & 1 & 2 & - & - & 14 \\
36 & 6 & 4 & 4 & - & - & - & - & 1 \\
41 & - & 1 & - & - & - & - & - & 1 \\
42 & 1 & - & 1 & - & - & - & - & 71 \\
43 & 1 & - & - & - & - & - & - & 133 \\
44 & - & - & 1 & - & - & - & - & 1 \\
Subtotal & 38 & 13 & 13 & 4 & 2 & - & 1 & 204 \\
Surface & 75 & 49 & 4 & 3 & - & 2 & - & 1 \\
\hline Totals & 113 & 62 & 17 & 7 & 2 & 2 & 1 & \\
\hline
\end{tabular}

$\mathrm{PS}=$ plain sherd; $\mathrm{DS}=$ decorated sherd; $\mathrm{LD}=$ lithic debris; $\mathrm{AB}=$ animal bone; $\mathrm{NS}=$ nutshell; $\mathrm{BC}=$ burned clay; $\mathrm{MD}=$ mud dauber nest fragment

The mean density of artifacts in the shovel testing is 5.1 per positive shovel test, or ca. 40.8 artifacts per square meter of archaeological deposits. The highest densities of artifacts - and the only shovel tests that contain animal bone and charred nutshells (Table 4) - occur in ST 34-ST 36 in a significant Caddo habitation deposit not far to the southeast of the earthen mound (see Figure 2).

\section{Material Culture Assemblage}

The most common material culture remains recovered in the January 2016 archaeological investigations from the M. S. Roberts are ceramic vessel sherds from plain, utility, and fine wares (Table 5). Utility wares and fine wares comprise only 29 percent of the sherds, with the remainder of the sherds identified as plain ware rim, body, and base fragments. More than 93 percent of the sherds are from grog-tempered vessels; bone-tempered sherds account for only 6.2 percent of this assemblage, including 7.9 percent of the utility wares and 6.2 percent of the plain wares. None of the fine ware sherds are from bone-tempered vessels. Another 121 ceramic vessel sherds and seven chipped stone artifacts were recovered in a February 2016 surface collection (see Appendix 2, this article) 
Table 5. Ceramic Wares from the January 2016 investigations at the M. S. Roberts site.

\begin{tabular}{lccc}
\hline Ware & Grog-tempered & Bone-tempered & N \\
\hline Plain & 258 & 17 & 275 \\
Utility & 82 & 7 & 89 \\
Fine & 24 & - & 24 \\
\hline Totals & 364 & 24 & 388 \\
\hline
\end{tabular}

In the January 2016 decorated sherd assemblage, 78.8 percent of the sherds are from utility wares and the remaining 21.2 percent are from fine wares (Table 6). The most common of the utility wares are sherds with incised elements (49 percent of the utility wares), including sherds with cross-hatched, diagonal, and opposed incised elements. Although the typological identifications are uncertain, such decorative elements are present in jars and carinated bowls of the Canton Incised and Maydelle Incised types (see Suhm and Jelks 1962). One rim sherd has a distinctive horizontal and diagonal opposed incised element (Figure 8c).

Table 6. Decorative methods and elements in the January 2016 ceramic sherd sample from the M. S. Roberts site.

\begin{tabular}{lll}
\hline Decorative Method and Element & Rim & Body \\
\hline
\end{tabular}

\section{Utility Ware}

\section{Appliqued}

straight appliqued fillet

straight appliqued ridge

$\begin{array}{lll}- & 1 & 1 \\ - & 1 & 1 \\ & & \\ - & 1 & 1 \\ - & 10 & 10\end{array}$

Brushed

opposed brushed

parallel brushed

$\begin{array}{lll}- & 1 & 1 \\ & & \\ - & 1 & 1 \\ & & \\ & & \\ - & 1 & \\ & & 1 \\ - & & \\ - & 1 & 9 \\ 2 & 1 & 1 \\ 1 & - & 1 \\ 1 & - & 1\end{array}$

Brushed-Incised

parallel brushed and overlying diagonal incised lines

Brushed-Incised-Punctated

vertical punctated row, vertical brushing, and diagonal

incised lines overlying brushing marks

Brushed-Punctated

parallel brushed with tool punctated row through the brushing

Incised

cross-hatched incised lines

curvilinear incised line

diagonal incised lines

horizontal and diagonal incised lines

horizontal and opposed diagonal incised lines 
Table 6. Decorative methods and elements in the January 2016 ceramic sherd sample from the M. S. Roberts site, cont.

\begin{tabular}{|c|c|c|c|}
\hline Decorative Method and Element & Rim & Body & $\mathrm{N}$ \\
\hline \multicolumn{4}{|l|}{ Utility Ware } \\
\hline horizontal and vertical incised lines & 1 & - & 1 \\
\hline opposed incised lines & - & 2 & 2 \\
\hline parallel incised lines & - & 10 & 10 \\
\hline straight incised line & - & 15 & 15 \\
\hline vertical incised lines & 1 & - & 1 \\
\hline \multicolumn{4}{|l|}{ Incised-Punctated } \\
\hline parallel incised lines and overlying fingernail punctated rows & - & 1 & 1 \\
\hline straight incised line and adjacent tool punctated row & - & 2 & 2 \\
\hline triangle incised zone filled with tool punctates & 1 & - & 1 \\
\hline \multicolumn{4}{|l|}{ Punctated } \\
\hline circular punctated rows & - & 1 & 1 \\
\hline fingernail punctated rows & - & 12 & 12 \\
\hline single fingernail punctate & - & 1 & 1 \\
\hline tool punctated rows & 1 & 7 & 8 \\
\hline linear tool punctated rows & 1 & 2 & 3 \\
\hline
\end{tabular}

\section{Fine Ware}

Engraved

bracket el.

curvilinear engraved line

diagonal engraved lines

horizontal engraved lines

horizontal and diagonal engraved lines

opposed engraved lines

parallel engraved lines

rectilinear engraved element

straight engraved line

$\begin{array}{lll}- & 1 & 1 \\ - & 2 & 2 \\ - & 1 & 1 \\ 1 & - & 1 \\ - & 1 & 1 \\ - & 1 & 1 \\ - & 4 & 4 \\ 1 & - & 1 \\ - & 4 & 4\end{array}$

\section{Red-Slipped}

int./ext. red-slipped

ext. red-slipped

\begin{tabular}{lcc}
- & 3 & 3 \\
- & 5 & 5 \\
\hline 11 & 102 & 113
\end{tabular}

Punctated sherds comprise 28 percent of the utility wares in this sample from the M. S. Roberts site, and these sherds have either fingernail, tool, or linear tool punctated elements. One rim sherd from a rim peaked jar with broad strap handles (from ST 35) has horizontal rows of tool punctations on the rim itself, as well as vertical tool punctated rows along the edges of the handle (Figure 9). 


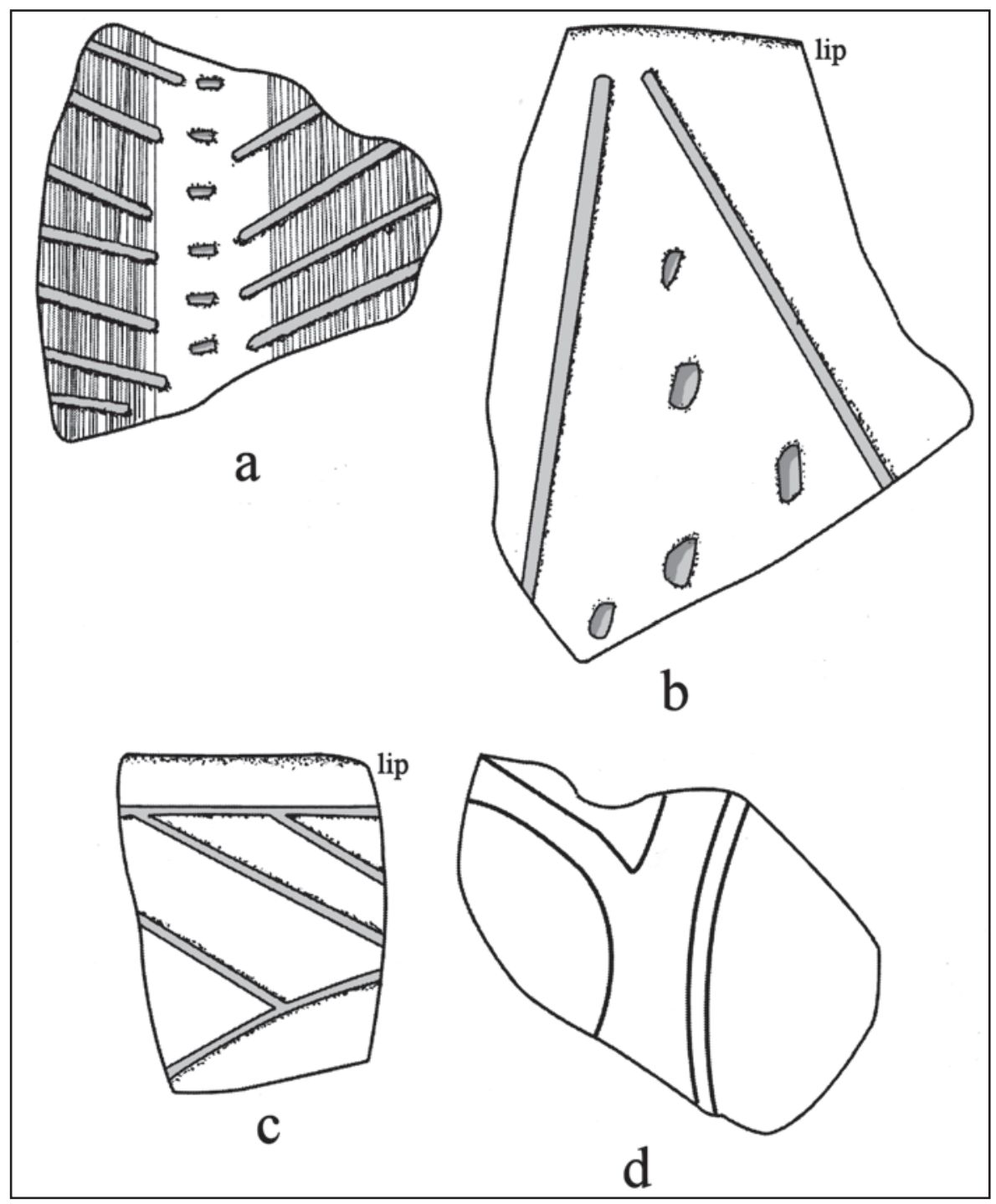

Figure 8. Selected decorative elements in utility ware and fine ware sherds from the M. S. Roberts site: a, brushed-incised-punctated body sherd (Surface); b, incised-punctated rim sherd (Unit 1, 10-20 cm bs); c, incised rim sherd (Unit 1, 20-30 cm bs); d, engraved body sherd (Unit 1, 20-30 cm bs).

Sherds with brushed decorative elements, either as the sole form of decoration, or in combination with brushed-incised, brushed-punctated, and brushed-incised-punctated (see Figure 8a) elements, comprise 15.7 percent of the utility ware sherds (see Table 8 ). The brushed, brushed-incised, and brushedpunctated sherds are probably from Bullard Brushed jars.

Other utility wares have appliqued (2.2 percent of the utility wares) and incised-punctated (4.5 percent) decorative elements (see Table 6). The one incised-punctated rim sherd, from either a Canton Incised or Maydelle Incised vessel, has an incised triangle zone on the rim that is filled with tool punctations (see Figure 8b).

The engraved fine ware sherds from the site are primarily simple geometric elements (see Table 6) on carinated bowls and bowls. Two have a single curvilinear engraved line, and may be from bottles, and one rim has rectilinear engraved elements. One body sherd has an engraved bracket element (see Figure 


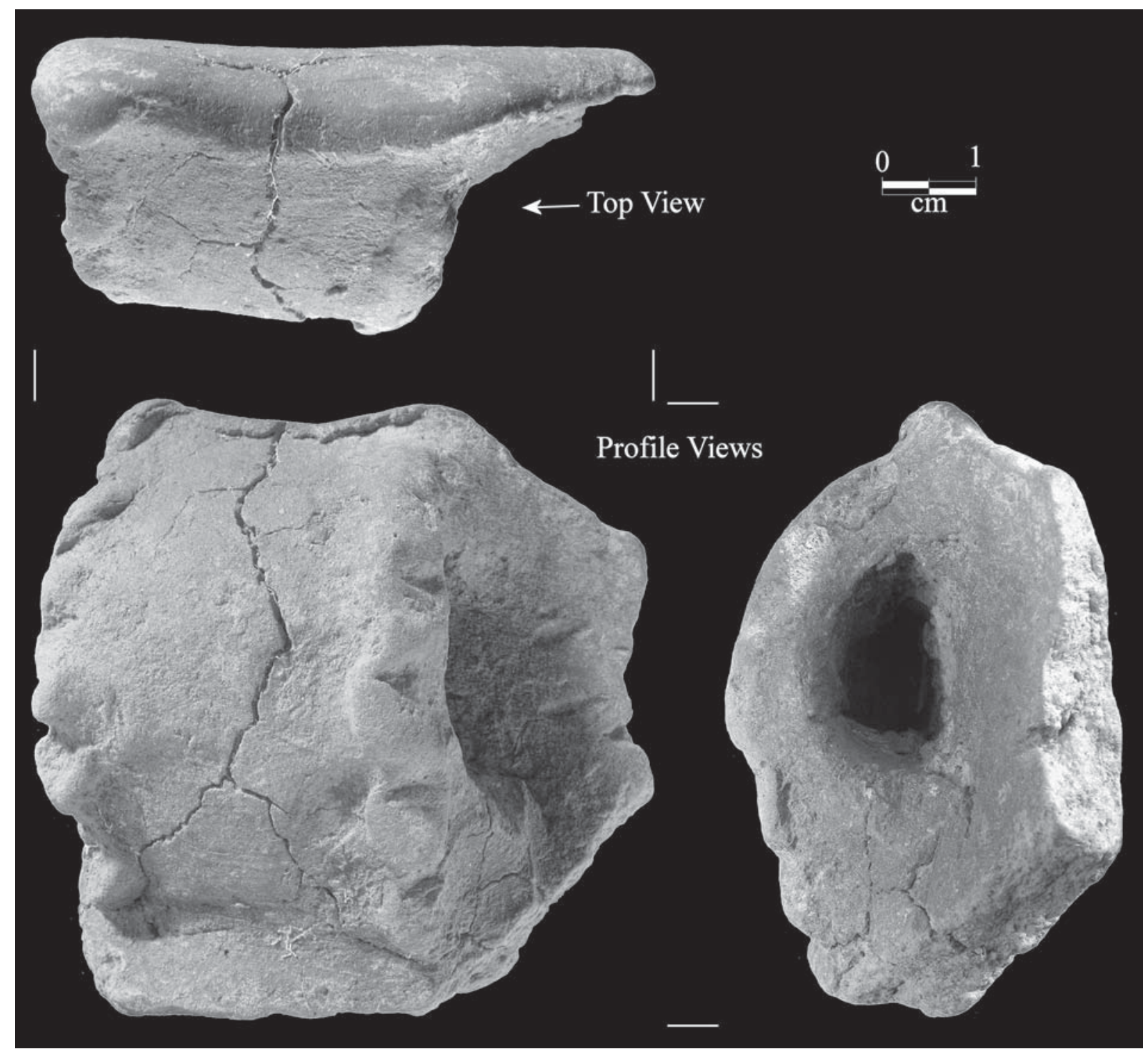

Figure 9. Punctated rim and punctated handle ceramic sherd, ST 35, 20-40 cm bs.

8d). About 6.3 percent of the engraved sherds (from ST 36, 0-20 $\mathrm{cm}$ bs0 have a red ochre-rich pigment rubbed in the engraved lines, but none of the engraved sherds have a red slip. However, 33 percent of the fine ware sherds have a red slip on one or both vessel surfaces (see Table 6), and at least one of these sherds is from a bottle (Unit 2, 40-50 cm bs). These sherds are likely from Sanders Slipped vessels (see Perttula, Walters, and Nelson 2016:87).

Three ceramic pipe sherds from grog-tempered long-stemmed Red River style pipes (see Hoffman 1967) were recovered between $20-30 \mathrm{~cm}$ bs in Unit 2. The two partial pipe stems range from 2.3-3.8 $\mathrm{mm}$ in wall thickness, and the one rim sherd has a rounded lip and $3.4 \mathrm{~mm}$ thick walls. These sherds are likely from a Haley variety of Red River pipe (Hoffman 1967:10 and Figure 5).

The combined ceramic vessel sherd assemblage from the M. S. Roberts site (see Perttula 2016; Perttula and Walters 2016; Perttula et al. 2016) is provided in Table 7. As can be seen, 91.5 percent of the sherds are from vessels tempered with grog (either as the sole temper or in association with burned bone), and 11.3 percent of the sherds are from vessels tempered with burned bone. Sherds from utility ware vessels comprise 79.1 percent of the decorated sherds, and most of these are from vessels with 
incised, punctated (mainly fingernail or tool elements), or brushed decorative elements. Fine ware sherds in the M. S. Roberts assemblage are either from engraved or red-slipped vessels (see Table 7). The proportion of red-slipped sherds in the decorated sherd assemblage (5.2 percent, and 25 percent of the fine ware sherds) is notable, particularly given the relatively common manufacture of red-slipped vessels in parts of East Texas during the Middle Caddo period (see Perttula 2013).

Table 7. Summary of the ceramic sherd assemblage from the M. S. Roberts site.

\begin{tabular}{lll}
\hline Temper/ & $\mathrm{N}$ & $\%$ \\
Decorative Method & 813 & 88.7 \\
\hline Grog temper & 26 & 2.8 \\
$\begin{array}{l}\text { Grog-bone temper } \\
\text { Bone temper }\end{array}$ & 78 & 8.5 \\
$\begin{array}{l}\text { Subtotal, sherds analyzed } \\
\text { for temper }\end{array}$ & 917 & 100.0
\end{tabular}

Utility Ware

$\begin{array}{lll}\text { Appliqued } & 7 & 1.8 \\ \text { Brushed } & 55 & 14.4 \\ \text { Brushed-Incised } & 13 & 3.4 \\ \text { Brushed-Incised-Punctated } & 1 & 0.3 \\ \text { Brushed-Punctated } & 2 & 0.5 \\ \text { Incised } & 124 & 32.3 \\ \text { Incised-Punctated } & 17 & 4.5 \\ \text { Punctated } & 84 & 21.9 \\ \text { Utility Ware } & 303 & 79.1\end{array}$

Fine Ware

\begin{tabular}{cll} 
Engraved & 60 & 15.7 \\
Slipped & 20 & 5.2 \\
Fine Ware & 80 & 20.9 \\
\hline Decorated sherds & 383 & 100.0 \\
\hline
\end{tabular}

Source: Perttula 2016; Perttula and Walters 2016; Perttula et al. 2016; this article

Analyses of the character of ancestral Caddo ceramic sherd assemblages from 41 different components and/or sites in the upper Neches River basin in East Texas have identified several temporal changes in (1) the proportion of brushed sherds in decorated sherd assemblages; (2) the percentage of other wet paste decorations (i.e., incised, incised-punctated, punctated, etc.) on sherds; (3) changes in the ratio of plain to decorated sherds (P/DR); (4) the use of burned bone as a ceramic vessel temper; and (5) the ratio of brushed sherds to other wet paste decorated sherds (Table 8 ). These analyses have led to the recognition of six temporal sequent groups of assemblages, dating from as early as ca. A.D. 1000-1200 in the Early Caddo period (Group VI) to Historic Caddo ceramic assemblages (Group I) that date after ca. A.D. 1680. 
Table 8. Comparative sherd assemblage data from Lake Palestine Caddo sites, nearby Caddo sites, and the M. S. Roberts site in the upper Neches River basin.

\begin{tabular}{|c|c|c|c|c|c|c|}
\hline Site & $\begin{array}{l}\text { No. of Dec. } \\
\text { Sherds }\end{array}$ & \% Brushed & $\begin{array}{l}\text { \%bone- } \\
\text { temper }\end{array}$ & $\begin{array}{c}\% \text { Wet-paste } \\
\text { decorations }\end{array}$ & $\mathbf{P} / \mathbf{D R}$ & $\begin{array}{l}\text { Brushed/Wet } \\
\text { paste ratio }\end{array}$ \\
\hline \multicolumn{7}{|c|}{ YOUNGEST SITES: GROUP I, Allen phase, ca. post-A.D. 1680} \\
\hline $41 \mathrm{CE} 421 *$ & 1805 & 88.1 & 5.4 & 7.8 & 0.28 & 8.5 \\
\hline $41 \mathrm{CE} 429 *$ & 465 & 87.7 & 0.8 & 9.7 & 0.22 & 9.07 \\
\hline Pine Snake* & 305 & 85.2 & 5.7 & 8.8 & 0.51 & 9.63 \\
\hline 41CE354* & 474 & 82.7 & 3.1 & 8.9 & 0.20 & 8.14 \\
\hline \multicolumn{7}{|c|}{ GROUP II, latest Frankston phase, ca. A.D. 1560-1680 } \\
\hline 41HE22 & 228 & 85.5 & $?$ & 7.5 & 0.62 & 11.5 \\
\hline 41AN1 & 295 & 83.1 & 5.1 & 7.1 & 0.19 & 7.21 \\
\hline $41 \mathrm{CE} 324$ & 188 & 81.9 & 3.2 & 7.3 & 0.48 & 11.0 \\
\hline Attaway & 814 & 84.4 & $?$ & 10.6 & 1.71 & 8.0 \\
\hline Debro & 311 & 80.0 & $?$ & 10.3 & 0.14 & 7.75 \\
\hline 41SM91 & 191 & 75.9 & 0.7 & 14.7 & 0.51 & 5.18 \\
\hline $41 \mathrm{AN} 21 *$ & 133 & 75.9 & 1.1 & 17.1 & 0.30 & 5.32 \\
\hline $\begin{array}{l}\text { William } \\
\text { Sherman }\end{array}$ & 525 & 75.8 & $?$ & 16.2 & 0.44 & 4.68 \\
\hline A. C. Saunders & 5805 & 74.5 & 15.5 & 14.4 & 0.21 & 5.30 \\
\hline $41 \mathrm{AN} 8 *$ & 98 & 70.4 & 3.3 & 18.3 & 0.55 & 3.83 \\
\hline $41 \mathrm{AN} 2 *$ & 152 & 67.8 & 11.5 & 17.8 & 0.41 & 3.81 \\
\hline \multicolumn{7}{|c|}{ GROUP III, Frankston phase, ca. A.D. 1480-1560 } \\
\hline Forest Drive & 1693 & 68.6 & $?$ & 21.9 & 0.56 & 3.12 \\
\hline Halbert & 1757 & 65.8 & 2.6 & 26.3 & 0.70 & 2.51 \\
\hline Woldert & 1730 & 62.7 & 0.0 & 28.8 & 0.72 & 2.19 \\
\hline Ferguson & 4116 & 60.8 & $<1.0$ & 27.9 & 0.61 & 2.17 \\
\hline \multicolumn{7}{|c|}{ GROUP IV, earliest Frankston phase, ca. A.D. 1400-1480 } \\
\hline 41SM87 & 176 & 56.2 & 1.8 & 34.1 & 1.24 & 1.65 \\
\hline $41 \mathrm{HE} 4 / 55^{* *}$ & 70 & 51.4 & $?$ & 40.0 & 1.54 & 1.29 \\
\hline 41SM90 & 85 & 50.6 & 2.9 & 31.8 & 2.20 & 1.60 \\
\hline Tomato Patch & 912 & 49.2 & $?$ & 41.7 & 1.50 & 1.21 \\
\hline 41SM89 & 136 & 39.0 & 10.4 & 44.1 & 1.96 & 0.88 \\
\hline 41SM88 & 95 & 37.9 & $?$ & 49.5 & 1.53 & 1.31 \\
\hline $\begin{array}{l}\text { Henderson Co. } \\
\text { site**** }\end{array}$ & 116 & 37.1 & 5.4 & 41.4 & 1.21 & 0.90 \\
\hline Lang Pasture & 2435 & 35.9 & 6.7 & 38.0 & 1.40 & 0.91 \\
\hline 41AN7 & 119 & 35.3 & 3.5 & 35.3 & 2.11 & 1.0 \\
\hline Mitchell, D & 54 & 32.1 & 0.0 & 33.3 & 1.37 & 1.50 \\
\hline 41HE337 & 149 & 35.6 & 5.6 & 46.3 & 2.25 & 0.76 \\
\hline \multicolumn{7}{|c|}{ GROUP V, Middle Caddo period, ca. A.D. 1200-1400 } \\
\hline 41SM73 & 165 & 26.1 & $?$ & 72.7 & 2.61 & 0.37 \\
\hline M. S. Roberts & 383 & 18.6 & 11.4 & 60.6 & 2.05 & 0.29 \\
\hline 41SM404 & 446 & 16.0 & 8.5 & 60.7 & 1.73 & 0.26 \\
\hline
\end{tabular}


Table 8. Comparative sherd assemblage data from Lake Palestine Caddo sites, nearby Caddo sites, and the M. S. Roberts site in the upper Neches River basin, cont.

\begin{tabular}{|c|c|c|c|c|c|c|}
\hline Site & $\begin{array}{l}\text { No. of Dec. } \\
\text { Sherds }\end{array}$ & \% Brushed & $\begin{array}{l}\text { \%bone- } \\
\text { temper }\end{array}$ & $\begin{array}{l}\text { \%Wet-paste } \\
\text { decorations }\end{array}$ & $\mathbf{P} / \mathbf{D R}$ & $\begin{array}{l}\text { Brushed/Wet } \\
\text { paste ratio }\end{array}$ \\
\hline \multicolumn{7}{|c|}{ GROUP V, Middle Caddo period, ca. A.D. 1200-1400, cont. } \\
\hline White Mule & 1404 & 18.5 & 1.5 & 63.7 & 2.61 & 0.29 \\
\hline 41HE139 & 40 & 17.5 & 8.1 & 65.0 & 2.51 & 0.33 \\
\hline 41HE139 & 40 & 17.5 & 8.1 & 65.0 & 2.51 & 0.33 \\
\hline 41AN159 & 23 & 13.0 & 13.9 & 65.2 & 3.39 & 0.20 \\
\hline 41SM273, Z1/2 & 256 & 10.9 & 28.8 & 70.0 & 3.97 & 0.16 \\
\hline 41SM273, Z3 & 155 & 9.7 & 32.3 & 73.5 & 3.80 & 0.13 \\
\hline \multicolumn{7}{|c|}{ OLDEST SITE: GROUP VI, Early Caddo period, ca. A.D. 1000-1200 } \\
\hline Mitchell, A-C & 56 & 1.3 & 12.0 & 65.7 & 1.71 & 0.03 \\
\hline 41SM87 & 36 & 0.0 & $?$ & 69.4 & 4.44 & 0.00 \\
\hline
\end{tabular}

$\mathrm{P} / \mathrm{DR}=$ plain to decorated sherd ratio

*sites with Patton Engraved sherds

**site is in the adjoining Coon Creek/Catfish Creek drainage in the Trinity River basin

***unrecorded site in the Caddo Creek valley

?=information not provided in Anderson et al. (1974)

This seriation suggests that the principal ancestral Caddo occupation of the M. S. Roberts site took place during the Middle Caddo period (see Table 8). This is based primarily on the relatively low proportion of sherds with brushed decorative elements in the assemblage (18.6 percent), the moderate P/DR (2.05), and the low ratio of brushed sherds to other wet paste sherds (0.29). None of the earliest Late Caddo period Frankston phase components have less than 32 percent brushed sherds in a decorated sherd assemblage; almost all have P/DR values less than 1.54, and have brushed to other wet paste sherd ratios that range from 0.76 to 1.65 (see Table 8 ).

Two burned mud dauber nest fragments come from ancestral habitation contexts at the M. S. Roberts site. The first is a small piece, with one empty nest cavity, from ST 34, 40-60 cm bs, about $10 \mathrm{~m}$ southeast of the southeastern part of the mound (see Figure 2). The other is a much larger fragment with at least two empty nest cavities (Figure 10) that was recovered in situ (with a bottom depth of $31 \mathrm{~cm} \mathrm{bs}$ ) from the profile of a burned structure context in Unit 1, Zone $2 b$ (see Figure $5 b$ ).

In addition to one piece of ferruginous sandstone fore-cracked rock from Unit 1 (20-30 cm bs), three ground stone tools have been recovered from mound and non-mound contexts at the M. S. Roberts site (Table 9). The ground stone tools - all on a local ferruginous sandstone-include a mano fragment from 10 $\mathrm{cm}$ bs in Unit 1, a mano fragment from $10-20 \mathrm{~cm}$ bs in Unit 1, and a mano/pitted stone from Unit 2. 

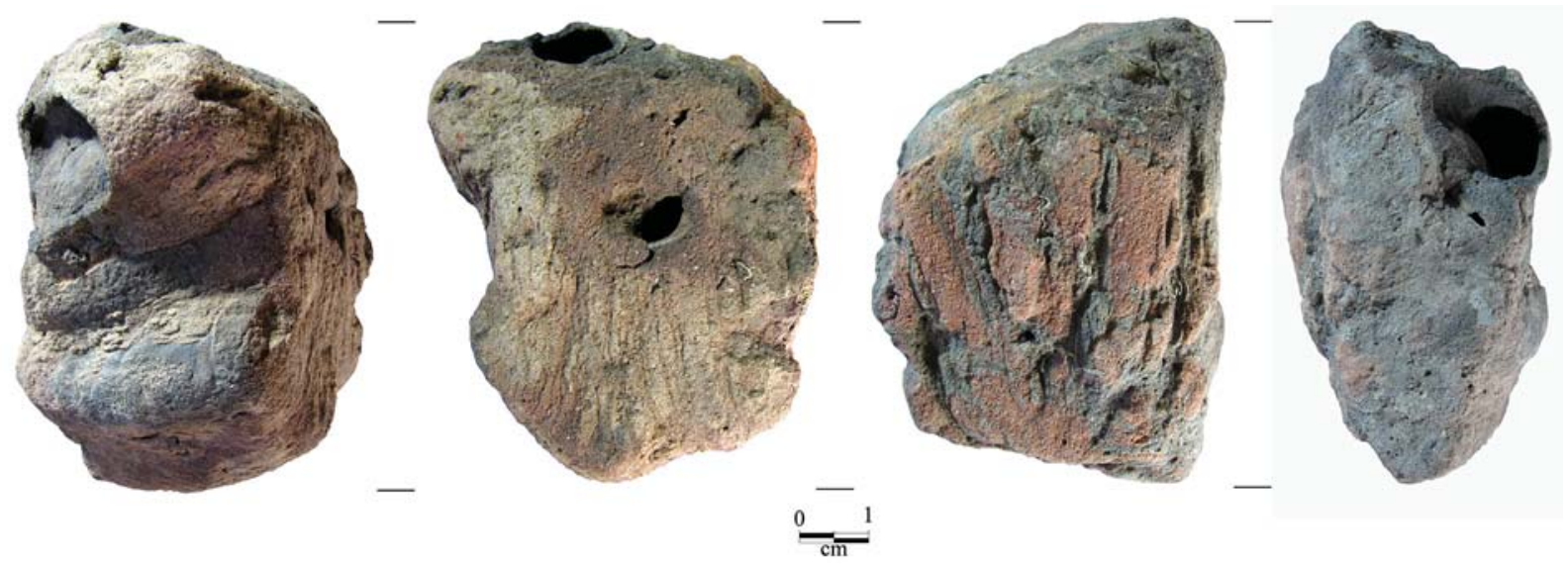

Figure 10. Mud dauber nest fragment from Unit 1, Zone 2b.

Table 9. Lithic artifacts from January 2016 investigations at the M. S. Roberts site.

\begin{tabular}{lllll}
\hline $\begin{array}{l}\text { Provenience } \\
\text { (cm bs) }\end{array}$ & Lithic Debris & Ground stone & FCR & N \\
\hline Surface & 4 & - & - & 4 \\
ST 26, 0-20 & 1 & - & - & 1 \\
ST 27, 40-60 & 1 & - & - & 1 \\
ST 34, 20-40 & 1 & - & - & 1 \\
ST 35, 0-20 & 2 & - & - & 2 \\
ST 35, 20-40 & 2 & - & - & 2 \\
ST 36, 0-20 & 4 & - & - & 4 \\
ST 42, 0-20 & 1 & - & - & 1 \\
ST 44, 20-40 & 1 & - & - & 1 \\
Unit 1, 0-10 & 1 & & - & 2 \\
Unit $1,10-20$ & 2 & 1 & - & 3 \\
Unit 1, 20-30 & 5 & 1 & 1 & 6 \\
Unit 2, 0-10 & 2 & - & - & 2 \\
Unit 2, 10-20 & 6 & - & - & 6 \\
Unit 2, 20-30 & 3 & - & - & 3 \\
Unit 2, 30-40 & 3 & - & - & 3 \\
Unit 2, 40-50 & 2 & 1 & - & 3 \\
\hline Totals & 41 & 3 & 1 & 45 \\
\hline
\end{tabular}

$\mathrm{FCR}=$ fire-cracked rock

The lithic debris in the assemblage (see Table 9) is predominantly comprised of pieces knapped from chert raw materials ( 80 percent), much of which was either available in Neches River gravels to the east of the site, or in stream gravels in drainages to the west of the Neches River. The cherts are of various colors, mainly shades of gray: very dark gray ( $n=1,0$ percent cortical), dark gray $(n=6,0$ percent cortical), gray ( $n=12,17$ percent cortical), light gray $(n=2,0$ percent cortical), dark grayish-brown $(n=1,0$ percent cortical), brownish-gray chert ( $n=3,0$ percent cortical), grayish-brown ( $n=3,67$ percent corti- 
cal), dark brown ( $\mathrm{n}=1,100$ percent cortical), reddish-brown ( $\mathrm{n}=1,0$ percent cortical), brown ( $\mathrm{n}=1,100$ percent cortical), bluish-gray ( $\mathrm{n}=1,0$ percent cortical), and white ( $\mathrm{n}=1,0$ percent cortical). Also found in the lithic debris assemblage are a few pieces ( 20 percent) of petrified wood $(n=2,50$ percent cortical) and quartzite ( $\mathrm{n}=6,17$ percent cortical). About 18 percent of the chert lithic debris has stream-rolled cortical remnants, compared to 25 percent of the petrified wood and quartzite lithic debris.

Animal bones and charred plant remains are not abundant in the archaeological deposits at the M. S. Roberts site (Table 10). What is preserved includes deer bones and teeth, charred nutshells, and various pieces of wood charcoal either from non-mound habitation contexts south of the mound or at various depths in Unit 1 in the northern mound lobe. Five samples of either charred nutshells or unburned animal bone and teeth have been submitted to D-AMS (Seattle, Washington) for conventional AMS radiocarbon dating of mound and non-mound habitation deposits.

Table 10. Animal bones and charred plant remains from the M. S. Roberts site.

\begin{tabular}{|c|c|c|c|c|c|}
\hline $\begin{array}{l}\text { Provenience } \\
(\mathrm{cm} \mathrm{bs})\end{array}$ & AB-burned & AB-unburned & NS & WC & $\mathrm{N}$ \\
\hline Surface & 2 & 1 & - & - & 3 \\
\hline ST $34,20-40$ & 1 & - & - & - & 1 \\
\hline ST $34,40-60$ & 1 & 1 & - & - & 2 \\
\hline ST $35,40-60$ & - & 1 & 2 & - & 3 \\
\hline Unit $1,10-20$ & 1 & - & - & - & 1 \\
\hline Unit $1,20-30$ & 1 & - & - & 4 & 5 \\
\hline Unit $1,30-35$ & - & - & - & 5 & 5 \\
\hline Unit 1,37 & - & 4 & - & - & 4 \\
\hline Unit 1,54 & - & 7 & - & - & 7 \\
\hline Unit 1,77 & 3 & - & - & - & 3 \\
\hline Unit 1,80 & - & - & - & 11 & 11 \\
\hline Unit 2, 20-30 & - & - & 3 & 4 & 7 \\
\hline Unit $2,30-40$ & - & - & 3 & 1 & 4 \\
\hline Unit $2,40-50$ & - & - & 2 & 10 & 12 \\
\hline Totals & 9 & 14 & 10 & 35 & 68 \\
\hline
\end{tabular}

$\mathrm{AB}=$ animal bone; $\mathrm{NS}=$ nutshell; $\mathrm{WC}=$ wood charcoal

\section{Summary and Conclusions}

Archaeological investigations were continued at the M. S. Roberts site (41HE8) in the upper Neches River basin in East Texas in January 2016, along with geophysical investigations completed by Dr. Duncan P. McKinnon (University of Central Arkansas, see elsewhere in this volume) and further aerial survey work by Arlo McKee (University of Texas-Dallas). This work was done with the permission and support of Jim and Denise Renfroe, the landowners. 
The archaeological work summarized herein focused on delimiting intact non-mound habitation areas at the site as well as investigating the northern and southern ends of the mound (to a depth of ca. $100-110 \mathrm{~cm}$ bs) for evidence of structures, different mound fill zones, and preserved plant and animal remains. The character of the decorated ceramic sherds in this work, as well as previous investigations, at the site suggest that the M. S. Roberts site was occupied during the Middle Caddo period, perhaps in the $14^{\text {th }}$ century A.D. Samples of charred plant remains and animal bones recovered in the January 2016 work will provide definitive calibrated radiocarbon dates from both mound and non-mound contexts.

One of the units excavated in the mound (Unit 1) identified a zone (Zone 2b) with abundant charred plant remains and stains, as well as a large piece from a mud dauber nest, and this zone appears to represent the remains of a burned Caddo structure near the top of the mound. Mound zones were a combination of sandy loam and clay fills obtained from the nearby borrow pit, and are roughly comparable in character from one end of the mound to the other, except that no evidence for burned Caddo structures was apparent in the southern part of the mound; these remains may lie deeper in the mound, as was suggested by auger holes excavated to $140 \mathrm{~cm}$ bs in the mound in 2015 (Perttula et al. 2016:Figures 14).

Off-mound shovel testing identified a ca. 1200 square meter area southeast of the mound that has intact habitation deposits, including ceramic pipe sherds and a second piece of a burned mud dauber nest. The size of this habitation area, and the identification of a post hole in Unit 2, suggests that there may be at least one ancestral Caddo structure in this part of the M. S. Roberts site. While there are no midden deposits preserved here, small amounts of charred plant remains (i.e., nutshells and wood charcoal) were recovered throughout the archaeological deposits, along with ceramic vessel sherds and evidence of stone tool knapping.

\section{Acknowledgments}

First, we thank Jim and Denise Renfroe for permission to conduct archaeological work at this site on their property. We also thank Bo Nelson, Kevin Stingley, and Tom Middlebrook for their help in the archaeological investigations carried out at the M. S. Roberts site in January 2016. Sandra Hannum prepared Figure 1 for this article, while other figures were provided by Lance Trask and Mark Walters.

\section{References Cited}

Hoffman, M. P.

1967 Ceramic Pipe Style Chronology Along the Red River Drainage in Southwestern Arkansas. The Arkansas Archeologist 8(1):4-14.

Perttula, T. K.

2013 Caddo Ceramics in East Texas. Bulletin of the Texas Archeological Society 84:181-212.

Perttula, T. K., with contributions by W. Troell

2016 The A. S. Mann (41HE7) and M. S. Roberts (41HE8) Sites in the Upper Neches River Basin, Henderson County, Texas. Journal of Northeast Texas Archaeology 59:1-19.

Perttula, T. K. and M. Walters

2016 Recent Artifact Surface Collections from the M. S. Roberts (41HE8) Mound Site in the Upper Neches River Basin in East Texas. Journal of Northeast Texas Archaeology 59:69-74. 
Perttula, T. K., A. McKee, M. Walters, and B. Nelson

2016 New Archaeological Investigations at the M. S. Roberts Site (41HE8) in the Caddo Creek Valley in Henderson County, Texas. Journal of Northeast Texas Archaeology 65:25-51.

Perttula, T. K., M. Walters, and B. Nelson

2016 Caddo Ceramic Vessels from the T. M. Sanders Site (41LR2) on the Red River in Lamar County, Texas. Special Publication No. 41. Friends of Northeast Texas Archaeology, Austin and Pittsburg.

Suhm, D. A. and E. B. Jelks (editors)

1962 Handbook of Texas Archeology: Type Descriptions. Special Publication No. 1, Texas Archeological Society, and Bulletin No. 4, Texas Memorial Museum, Austin. Reprinted in 2009, Gustav's Library, Davenport, Iowa. 


\title{
Appendix 1, The Walter Brigham Site (41HE410)
}

\author{
Bo Nelson, Mark Walters, Kevin Stingley, and Timothy K. Perttula
}

The Walter Brigham site (41HE410) is an ancestral Caddo site located a short distance east of the M. S. Roberts site (41HE8). It was recorded during a January 2016 surface reconnaissance of landforms north of Caddo Creek in the upper Neches River basin, in an attempt to determine the spatial extent of the M. S. Roberts site.

This site is on a grass-covered lower ridge slope of an upland landform (400 ft. amsl), about $200 \mathrm{~m}$ west of a southward-flowing tributary of Caddo Creek. The landform has Wolfpen loamy fine sand sediments. The surface reconnaissance of the landform indicates the site covers a ca. $110 \mathrm{x} 130 \mathrm{~m}$ area $(3.5$ acres) area; no shovel testing was conducted at that time to determine the depth or extent of its subsurface archeological deposits.

Archaeological materials recovered in gopher mounds and other surface exposed areas includes 16 Caddo ceramic vessel sherds and 12 pieces of lithic debris. The ceramic sherds are from grog $(n=13,81$ percent) and grog-bone ( $n=3,19$ percent)-tempered vessels. There are six plain body sherds, one grogtempered base sherd, and nine sherds from decorated vessels; the plain to decorated sherd ratio in this small assemblage is 0.78 . Two of the sherds are from engraved fine ware vessels, including a rim with a horizontal engraved line beneath the lip and a body sherd with parallel engraved lines. The utility ware sherds include a body sherd with a single straight incised line and six body sherds with parallel brushing marks; these sherds are from Bullard Brushed vessels. The proportion of brushed sherds among all the decorated sherds (67 percent) is consistent with a post-A.D. 1480 Late Caddo period Frankston phase occupation (Perttula 2016).

The lithic debris from the surface of the Walter Brigham site includes pieces of chert ( $n=9)$, petrified wood $(n=2)$, and quartzite $(n=1)$. The chert pieces are gray $(n=3,67$ percent cortical $)$, light gray $(n=2)$, grayish-brown $(n=1)$, brownish-gray $(n=1)$, white $(n=1)$, and blackish-gray $(n=1)$ colors. These chert raw materials were probably gathered from gravels in the Neches River, or came from sources in the Trinity River and other western stream beds.

\section{References Cited}

Perttula, T. K.

2016 Utility Ware Ceramic Metrics and Hasinai Caddo Archaeology in East Texas. Journal of Northeast Texas Archaeology 70:61-68. 


\title{
Appendix 2, February 2016 Surface Collection from the M. S. Roberts Site (41HE8)
}

\author{
Timothy K. Perttula, Mark Walters, and Bo Nelson
}

In February 2016, in conjunction with the archaeological reconnaissance of other properties on the north side of Caddo Creek, another surface collection of ancestral Caddo artifacts was obtained from the M. S. Roberts site (41HE8). The collection, described herein, has 121 ceramic vessel sherds, one chipped stone flake tool, and six pieces of lithic debris.

\section{Ceramic Vessel Sherds}

The February 2016 surface collection has ceramic vessel sherds from plain, utility, and fine ware vessels (Table A2-1). The plain to decorated sherd ratio in this assemblage is 2.27 , and 65 percent of the decorated sherds are from utility wares. About 87.6 percent of the sherds are from grog-tempered vessels and the remainder are from bone-tempered vessels.

Table A2-1. Ceramic vessel sherds recovered in the February 2016 surface collection at the M.S. Roberts site.

\begin{tabular}{lccc}
\hline Ware & Grog-tempered & Bone-tempered & N \\
\hline Plain & 73 & 11 & 84 \\
Utility & 22 & 2 & 24 \\
Fine & 11 & 2 & 13 \\
\hline Totals & 106 & 15 & 121 \\
\hline
\end{tabular}

The most common utility wares in this assemblage from the M. S. Roberts site - and in this assemblage for the site as a whole (see below) - have incised and punctated decorative elements (Table A2-2). The most distinctive sherd from an incised vessel has eight-to-left drawn diagonal incised lines on the vessel rim (Figure A2-1a). The punctated sherds have one or more rows of either fingernail or tool punctations. Brushed rim and body sherds comprise only 10.8 percent of the decorated sherds in this assemblage, and there are also two sherds (one from a carinated bowl) from incised-punctated vessels (Figure A2-1b-c) and a body sherd with a straight appliqued fillet. 
Table A2-2. Decorative methods and elements in the utility and fine ware sherds recovered in the February 2016 surface collection.

\begin{tabular}{llll}
\hline $\begin{array}{l}\text { Decorative method and } \\
\text { decorative element }\end{array}$ & Rim & Body & N \\
\hline
\end{tabular}

\section{Utility Ware}

\section{Appliqued}

straight appliqued fillet

$\begin{array}{lll}- & 1 & 1 \\ & & \\ 1 & - & 1 \\ - & 3 & 3\end{array}$

\section{Brushed}

horizontal brushed

parallel brushed

Incised

diagonal incised lines

opposed incised lines

parallel incised lines

straight incised line

$\begin{array}{lll}1 & - & 1 \\ - & 3 & 3 \\ - & 1 & 1 \\ - & 1 & 1\end{array}$

\section{Incised-Punctated}

incised triangle el. filled with tool punctations

straight incised line and adjacent circular punctated row

$\begin{array}{lll}- & 2 & 2 \\ - & 1 & 1\end{array}$

\section{Punctated}

fingernail punctated rows

tool punctated rows

$\begin{array}{lll}- & 3 & 3\end{array}$

\section{Fine Ware}

\section{Engraved}

closely-spaced parallel engraved lines

closely-spaced curvilinear engraved lines

opposed engraved lines

parallel engraved lines

straight engraved line

triangle el. filled with horizontal and curvilinear

engraved lines

$\begin{array}{lll}- & 2 & 2 \\ 1 & - & 1 \\ - & 1 & 1 \\ - & 1 & 1 \\ - & 6 & 6 \\ - & 1 & 1\end{array}$

\section{Slipped}

int./ext. red-slipped

$-$

$1-1$

Totals

3

34

The fine ware sherds in the February 2016 surface collection include 12 engraved rim and body sherds and one red-slipped body sherd (see Table A2-2); one of the engraved sherds has a red pigment rubbed in the lines. One engraved sherd has opposed lines (see Figure A2-1f), while two others are from Poynor Engraved vessels. The first is a rim with closely-spaced curvilinear engraved lines (see Figure 


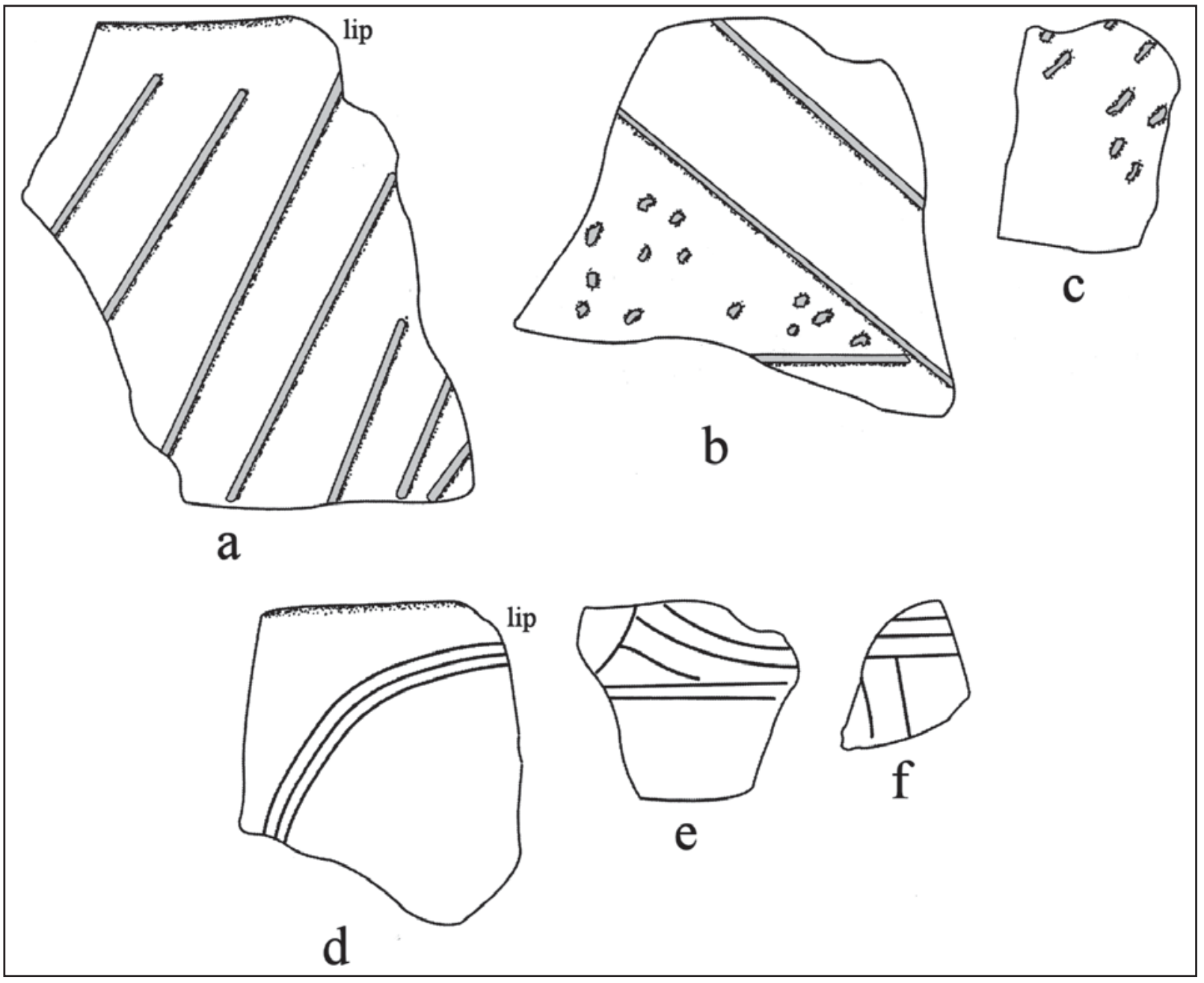

Figure A2-1. Selected decorative elements on ceramic vessel sherds in the February 2016 surface collection from the M. S. Roberts site: a, incised rim; b, incised-punctated body sherds; c, punctated body sherd; d, engraved rim; e-f, engraved body sherds.

A2-1d), likely from a Poynor Engraved, var. Cook carinated bowl (see Perttula 2011:Figure 6-64c). The second sherd, also from a carinated bowl, has an engraved triangle element filled with horizontal and curvilinear engraved lines (see Figure A2-1e). This specific element occurs on Poynor Engraved, var. Blackburn, var. Cook, and var. Lang vessels in the upper Neches River basin (see Perttula 2011:Figure 6-64b-b', d, f-g').

Including the ceramic vessel sherds from the February 2016 surface collection at the M. S. Roberts site, 91 percent of the analyzed sherds are from grog or grog-bone-tempered vessels (Table A2-3). Of the 420 rim and body sherds known to have come from either a utility ware or fine ware vessel, 77.9 percent are from utility ware vessels, primarily jars. These vessels principally have incised or punctated decorative elements (representing 53.3 percent of the total number of decorated sherds in the assemblage), and sherds with brushing - as the sole decorative method or in combination with incised or punctated elements - comprise only 17.8 percent of the decorated sherds from the M. S. Roberts site. 
Table A2-3. Summary of the ceramic sherd assemblage from the M. S. Roberts site, including the February 2016 surface collection.

\begin{tabular}{|c|c|c|}
\hline $\begin{array}{l}\text { Temper/ } \\
\text { Decorative Method }\end{array}$ & $\mathrm{N}$ & $\%$ \\
\hline Grog temper & 919 & 88.5 \\
\hline Grog-bone temper & 26 & 2.5 \\
\hline Bone temper & 93 & 9.0 \\
\hline Subtotal, sherds analyzed for temper & 1038 & 100.0 \\
\hline \multicolumn{3}{|l|}{ Utility Ware } \\
\hline Appliqued & 8 & 1.9 \\
\hline Brushed & 59 & 14.0 \\
\hline Brushed-Incised & 13 & 3.1 \\
\hline Brushed-Incised-Punctated & 1 & 0.2 \\
\hline Brushed-Punctated & 2 & 0.5 \\
\hline Incised & 132 & 31.4 \\
\hline Incised-Punctated & 20 & 4.8 \\
\hline Punctated & 92 & 21.9 \\
\hline Subtotal, Utility Ware & 327 & 77.9 \\
\hline \multicolumn{3}{|l|}{ Fine Ware } \\
\hline Engraved & 72 & 17.1 \\
\hline Slipped & 21 & 5.0 \\
\hline Subtotal, Fine Ware & 93 & 22.1 \\
\hline Totals, Decorated sherds & 420 & 100.0 \\
\hline
\end{tabular}

Source: Perttula 2016; Perttula and Walters 2016; Perttula et al. 2016; this article

The fine ware sherds from the M. S. Roberts site include sherds from either engraved or red-slipped vessels, including carinated bowls and bottles (see Table A2-3). They represent 22.1 percent of the decorated sherds in the assemblage as a whole. A few of the engraved sherds have an ochre-rich red clay pigment rubbed in the engraved lines.

\section{Chipped Stone Artifacts}

The flake tool in the surface collection is a gray chert expedient tool fragment with one use-worn edge. The use-worn edge is $10.2+\mathrm{mm}$ in length. Four of the recovered pieces of lithic debris are chert, probably of non-local origin of different colors: reddish-gray $(n=1)$, brownish-gray $(n=1)$, gray $(n=1)$, and gray-dark gray $(n=1)$; this latter piece has a stream-rolled cortex. 


\section{Summary and Conclusions}

This appendix describes the ceramic vessel sherds and chipped stone artifacts recovered at the M. S. Roberts site by Mark Walters and Bo Nelson in February 2016. The character and range of the artifacts found in this surface collection are much the same as those documented in all previous archaeological investigations at the site, beginning with those by A. T. Jackson in 1931, and provide a more robust assemblage of the material culture remains made and used by ancestral Caddo peoples at this $14^{\text {th }}$ to early $15^{\text {th }}$ century A.D. site in the upper Neches River basin in East Texas.

\section{References Cited}

Perttula, T. K.

2011 The Ceramic Artifacts from the Lang Pasture Site (41AN38) and the Place of the Site within an Upper Neches River Basin Caddo Ceramic Tradition. In Archeological Investigations at the Lang Pasture Site (41AN38) in the Upper Neches River Basin of East Texas, assembled and edited by T. K. Perttula, D. B. Kelley, and R.A. Ricklis, pp. 145-320. Archeological Studies Program Report No. 129, Texas Department of Transportation, Environmental Affairs Division, Austin. 